\title{
Reviewer Acknowledgements for Global Journal of Health Science, Vol. 11, No. 10
}

Global Journal of Health Science wishes to acknowledge the following individuals for their assistance with peer review of manuscripts for this issue. Their help and contributions in maintaining the quality of the journal are greatly appreciated.

Global Journal of Health Science is recruiting reviewers for the journal. If you are interested in becoming a reviewer, we welcome you to join us. Please find the application form and details at http://recruitment.ccsenet.org and e-mail the completed application form to gjhs@ccsenet.org.

\section{Reviewers for Volume 11, Number 10}

Abin Varghese, Ministry of Health and Family Welfare, India

Ama Pokuaa Fenny, University of Ghana, Ghana

Amy Clements-Cortes, University of Toronto, Canada

António Calha, Polytechnic Institute of Portalegre, Portugal

Ayesha Johnson, University of South Florida, United States of America

Celia Moffat Joel Matyanga, Harare Institute of Technology, Zimbabwe

David John Lindsay, James Cook University, Australia

David Otieno Odongo, Masinde Muliro University of Science and Technology, Kenya

Diadie Maiga, Management Sciences for Health in Arlington, United States of America

Emad Adel Shdaifat, Imam Abdulrahman Bin Faisal University, Saudi Arabia

Evangelia Mavrikaki, National \& Kapodistrian University of Athens, Greece

Evanthia Sakellari, Technological Educational Institute of Athens, Greece

Gabriele Messina, University of Siena, Italy

Georgann Valerie Weissman, Capella University, United States of America

Helen Lida Smits, Institute of Healthcare Improvement in Boston, United States of America

Hilal Hamood Alrahbi, Diwan of Royal Court-Oman, Oman

Hülya YARDIMCI, Ankara University, Turkey

Liye Suo, The Ohio State University, United States of America

Loray Daws, British Columbia Masterson Institute, Canada

Mini Sood, Monash University Malaysia, Malaysia

Raywat Deonandan, University of Ottawa, Canada

Samir Othman, Hawler Medical University, Iraq

Zohreh Vanaki, Tarbiat Modares University, Iran 